BIOMEDICAL AND BIOSOCIAL ANTHROPOLOGY
$\begin{gathered}\text { Official Journal of the International Academy } \\ \text { of Integrative Anthropology } \\ \text { journal homepage: http://bba-journal.com }\end{gathered}$

\title{
Morphological features of bone tissue in "disuse atrophy" on the example of a segment of the human lower jaw: clinical experience of treatment
}

Oshurko A. P., Oliinyk I. Yu., Yaremchuk N. I., Makarchuk I. S.

Bukovinian State Medical University, Chernivtsi, Ukraine

\section{ARTICLE INFO}

Received: 05 January 2021

Accepted: 09 February 2021

UDC: $616.716 .4 .018-007.23-091$

\section{CORRESPONDING AUTHOR}

e-mail: olijnyk1961@gmail.com Oliinyk I. Yu.

\begin{abstract}
Current real-time science and technology techniques based on ENDORET PRGF technologies and the implementation of their results in practical medicine, provide ample opportunities for the use of cell autotransplantation for guided tissue regeneration, including in the treatment of "disuse atrophy" of the human lower jaw bone tissue with early tooth loss. The purpose of this work is to ensure the principles of biological feasibility and physiological capacity, technical rationality. The pathology in the distal segment of a lower limb, which is a vertical atrophy of bone tissue was confirmed by the methods of computed tomography, Vatech PaX-I 3D Green systems of extra-oral radiography with a scan size range of $16 \times 9 \mathrm{~cm}$, a focal spot of $0.5 \mathrm{~mm}$ (IEC60336) with a gray scale of 14 bits with a size of $0.2 / 0.3$ voxel. Using ENDORET PRGF technology, according to the approved BTI protocol, autocellular grafts that have provided a positive result that meets the basic principles of the goal in restoring the mechanisms of physiological processes of normal quantitative and qualitative morphology of bone tissue, with its biological characteristics were obtained. The results of the study showed that bone tissue on a scale of shades of gray based on the classification of Hounsfield, is not characterized by a single biotype and in the area of missing 3.6 tooth belongs to the second biotype, and in the area of missing 3.7 tooth - to the first biotype by its density. The indicators of densitometric determination confirmed excessive mineralization of the trabecular layer, ie vertical atrophy of bone tissue, which is in the sagittal section in the projection of the missing 36 teeth - with a maximum number of 881 gray standard units (GSU), $M=315$ GSU (where, $M$ is the average value of absolute number); sagittal section in the projection of the missing 37 teeth - with a maximum number of 1726 GSU, M=1173 GSU. This clinical experience with the use of autocellular grafts in the treatment of "disuse atrophy" of the bone tissue of the jaws, which is essentially scientifically-research in nature, based on modern, at the same time available technologies of cell engineering and technical progress, provides a predictable result of clinical observation and deserves further research and practical testing. Keywords: atrophy, bone tissue, PRGF, autocellular grafts, augmentation.
\end{abstract}

\section{Introduction}

Every scientist or clinician in his professional development seeks to master and apply available universal $[22,24,32,46]$ at the same time relevant techniques in real time for the development of science and technology $[8,26]$ to implement their results in practical medicine. Studies using cell autotransplantation technologies $[2,6]$ for guided tissue regeneration $[7,20,33]$ including bone regeneration $[1,14,17]$, which are among such directions, have become popular in 2015-2016, which is confirmed by scientific publications of both domestic and foreign scientists. Many of them are based on ENDORET PRGF technologies [41], which improves and, in our opinion, combines existing PRF techniques (platentrichfibrin - platelet-enriched fibrin).

Significant improvement of regenerative processes through the use of the patient's own blood [18, 20] is a unique product concept of autogenous, universal and safe method of application, which contains growth factors and cytokines stored in the fibrin matrix and provide stimulating properties of tissue regeneration through the processes of angiogenesis, proliferation, cell migration and 
extracellular matrix synthesis.

The purpose of this work is to ensure the principles of biological feasibility and physiological capacity, technical rationality. The solution to this problem is selection of treatment methods and creation of conditions for restoration of barrier [9, 30], remodeling [10] functions, and also restoration of masticatory efficiency by methods of implantation $[4,16]$ with uniform distribution of occlusive load, formation of an oral lump (food grinding), providing phonetic and aesthetic requirements of the patient.

\section{Materials and methods}

The anamnesis of the disease of the patient $\mathrm{J}$. was clarified by the methods of clinical researches, the main etiological factor - early tooth loss, which became the consequent mechanism of atrophy of bone tissue of the cellular part of the lower jaw. Using computed tomography techniques, including Vatech PaX-I 3D Green extra-oral radiography systems with a scan size range of $16 \times 9 \mathrm{~cm}$, minimizing the possibility of artifacts caused by patient movement. Focal spot $0.5 \mathrm{~mm}$ (IEC60336) with a gray scale of 14 bits with a size of $0.2 / 0.3$ voxels and due to the short scan time, high-quality images were obtained (Fig. 1, 2), which remain and provide the best opportunities for diagnosis, while protecting the health of patients.

For guided bone regeneration, autocellular grafts were obtained using ENDORET PRGF technology, according to the approved BTI protocol. Using a vacutainer, autologous blood was collected in four sterile $9 \mathrm{ml}$ tubes with $0.9 \mathrm{ml}$ of $3.8 \%$ sodium citrate per $8.1 \mathrm{ml}$ of blood, followed by centrifugation $(580 \mathrm{~g})$ for 8 minutes at room temperature using a centrifuge for PRGF System V (VTI, Spain). Blood in vitro was divided into four layers: the upper layer - plateletpoor plasma (F1), the second - platelet-rich plasma (F2), the third layer $\pm 0.2 \mathrm{ml}$ of leukocytes, the lower layer - a clot of red blood cells. The resulting plasma in the upper two layers was divided into two fractions (F1 and F2) using a device for moving plasma PTD2. To activate coagulation and form a clot or fibrin membrane, calcium chloride $(0.5$ $\mathrm{ml}$ per $1 \mathrm{ml}$ of plasma) was added to the selected fractions
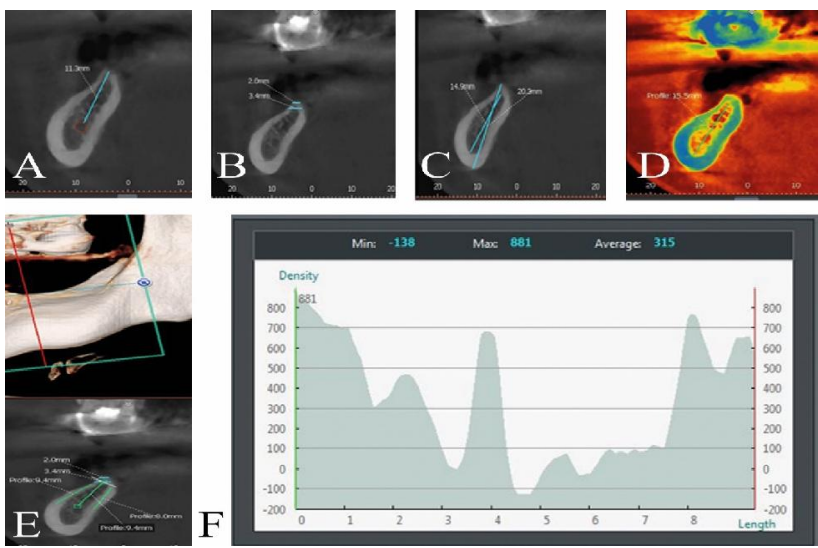

Fig. 1. Sagittal sections of SS1 with the results of morphometric and densitometric determination scale.
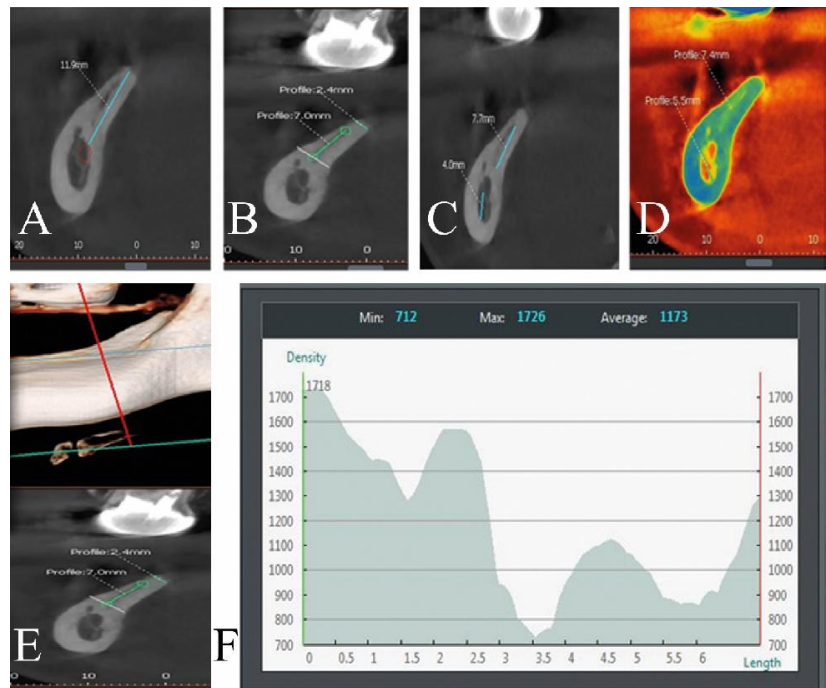

Fig. 2. Sagittal sections of SS2 with the results of morphometric and densitometric determination scale.

and the desired effect was achieved for $10 \mathrm{~min}$ in a PLAZMOTERM $\mathrm{H}$ furnace at a temperature of $36.8^{\circ} \mathrm{C}$.

The study was conducted in compliance with the basic provisions of GSR (1996), the Council of Europe Convention on Human Rights and Biomedicine (04.04.1997), the Helsinki Declaration of the World Medical Association on the ethical principles of scientific medical research with human participation. In accordance with the order of the Ministry of Health of Ukraine dated from 14.02.2012 No. 110 , informed voluntary consent of the patient for diagnosis, treatment and surgery and anesthesia was obtained, the relevant medical documentation was drawn up and certified by the signatures of patients. The norms of the Law of Ukraine dated from June 1, 2010 No. 2297-VI "On Personal Data Protection" as amended by the Laws of Ukraine dated from February 23, 2012 No. 4452-VI, dated from November 20,2012 No. 5491-VI, which regulates the legal relations related to the protection and processing of personal data, and aimed at protecting the fundamental rights and freedoms of man and citizen.

\section{Results}

Detailed analysis of computed tomography images in sagittal sections of the segment of the lower jaw on the left, in the projection of the missing 36 (first study segment, SS1), 37 (second study segment, SS2) teeth showed that bone tissue on a scale of shades of gray based on Hounsfield classification, is not characterized by one biotype and in the area of SS1 - refers to the second biotype, and in the area of SS2 refers to the first biotype by its density. However, the indicators of densitometric determination with excessive mineralization of the trabecular layer (Fig. 3, 4) attract attention, consisting of: sagittal section at the projection of the missing 36 teeth - with a maximum number of 881 gray standard units (GSU), $M=315$ GSU (where, $M$ is the average value of the absolute number); sagittal section 
in the projection of the missing 37 teeth - with a maximum number of $1726 \mathrm{GSU}, \mathrm{M}=1173 \mathrm{GSU}$. The reconstruction models are presented in the figures $(1 \mathrm{D}, 2 \mathrm{D})$ to visualize and confirm the described.

Morphometric values also show that there is a vertical atrophy of this segment and it is: SS1 - horizontal width of the upper edge of $2 \mathrm{~mm}$, the distance to the mandibular canal - $11.3 \mathrm{~mm}$; SS2 - horizontal width of the upper edge of $2.4 \mathrm{~mm}$, the distance to the mandibular canal $-11.9 \mathrm{~mm}$.

Given the research, taking into account the components of the updated clinical analysis, there are a number of tasks that must be considered when choosing methods of treatment and rehabilitation of the patient, namely: vertical loss of bone tissue of the cellular part and the body of the lower jaw (secondary final defect on the left of lower jaw); corticalization of the trabecular layer; unfavorable conditions for reconstructive operations, in particular bone tissue splitting; complex morphology of the body shape (sshaped) of the lower jaw; limited availability of the operating field; "complicated proposal" of choice methods; young age; trauma; unpredictable result.

Informed voluntary consent of the patient for treatment and surgery and anesthesia was obtained in accordance with the drawn up and agreed treatment plan, which provided: the stages of treatment (fig. 5); the anesthesia regional anesthesia; the use of autocellular grafts - guided regeneration of bone tissue using endoret prgF technology, Spain); the use of bone tissue allograft; the restoration of dentition defects using subcortical implants; the providing of a therapeutic effect and control of bone tissue mineralization and the prognosis of the formation of "biological height to width" around the implants [38].

The $V$ class (Cawood, 1988) was received after installation of implants $\varnothing 4.0 \times 7.5 \mathrm{~mm}$ in the projection of SS1 and SS2, which is presented in Fig. 6 and their positioning on the edentulous jaw.

Although high primary stabilization of implants with a force of $65 \mathrm{H}$, the result of their positioning in this clinical case, with a vertical defect, requires augmentation with osteoplastic materials with the predicted result of restoration of the vertical bone defect and achievement of positive remodeling processes [40]. Inorganic foreign body "causes" the reaction of bone tissue, with the manifestation of constant processes of resorption and appositional growth [43]. Important clinical results are the creation of conditions under which stable osteointegration of alloplastic material is achieved, in this case both of the implant and the bone augmentation [47, 51].

To achieve osteogenesis in the guided regeneration of bone tissue, we have provided: he presence of a matrix with osteoconductive properties (see Fig. 3-A, B, C); the processes of release of growth factors (see Fig. 3-B); the differentiation of osteogenic cells; the conditions of adequate blood supply; the stability and protection of blood clot in time (see Fig. 3-E; see Fig. 4-A, D, C).

The autologous membrane [30] of the fibrin clot (see
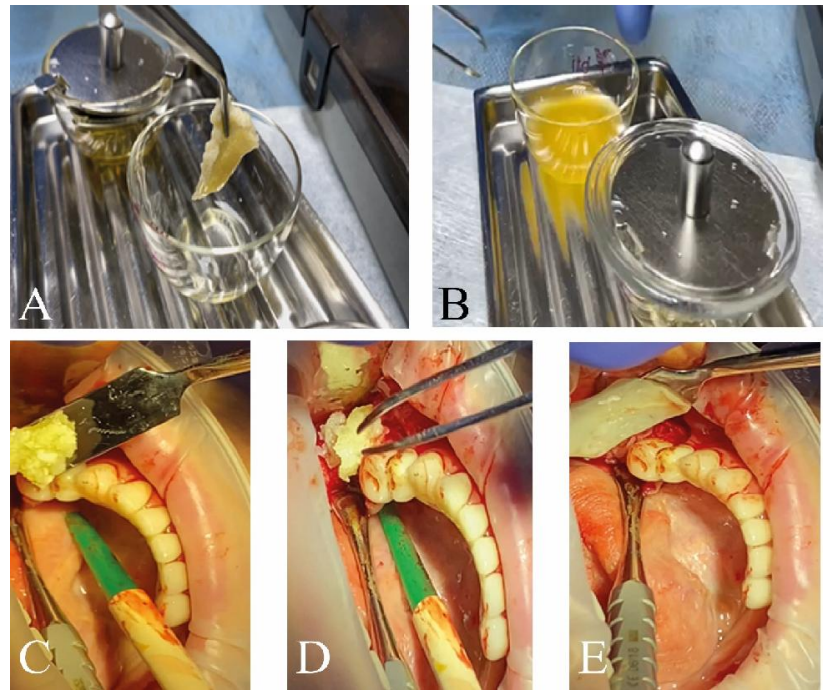

Fig. 3. Clinical stages of preparation $(A, B)$ and use $(C, D, E)$ of autocellular grafts in guided regeneration using bone tissue graft allograft.
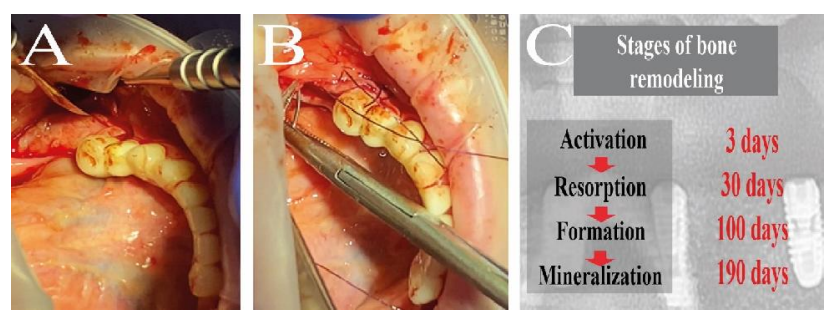

Fig. 4. Clinical stages of augmentation stabilization and blood clot protection $(A, B)$; Scheme of stages of remodeling processes in time (C - from lecture materials of Francsco Diez, 2021).
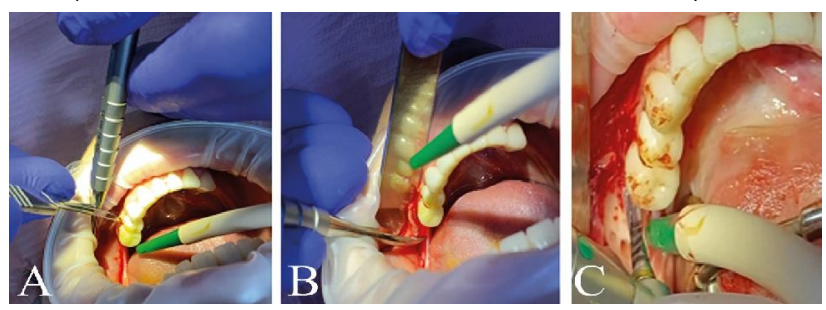

Fig. 5. Clinical stages of treatment: A - mucotomy; B - exfoliation of the mucous membrane; $\mathrm{C}$ - preparation of bone tissue under the implant bed.
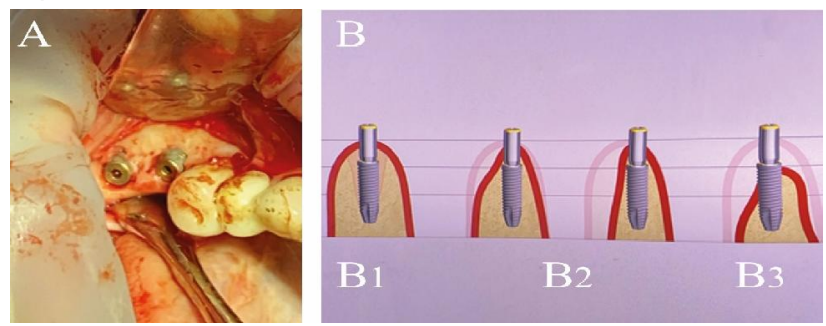

Fig. 6. A - clinical variant of positioning of implants on the edentulous fragment of the lower jaw on the left; $B$ - a schematic representation of the positioning of implants on edentulous jaws (Int $\mathrm{J}$ Oral Maxillofac Surg.1988 Aug: 17 (4): 232-6. A classification of the edentulous jaws. Cawood JII, Yowell RA).

Fig. 3-B, E; see fig. 4-A) promotes mechanical protection of the operating field and has a biological interaction with 


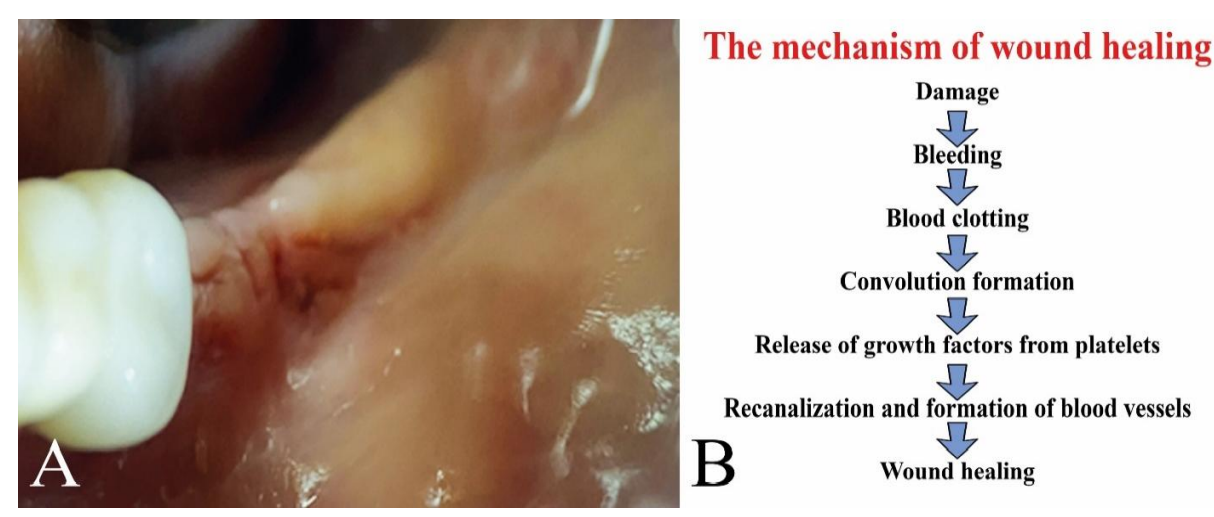

Fig. 7. The condition of the mucosa in the area of augmentation with simultaneous implantation using autocellular transplantation, day 14 (removal of sutures).
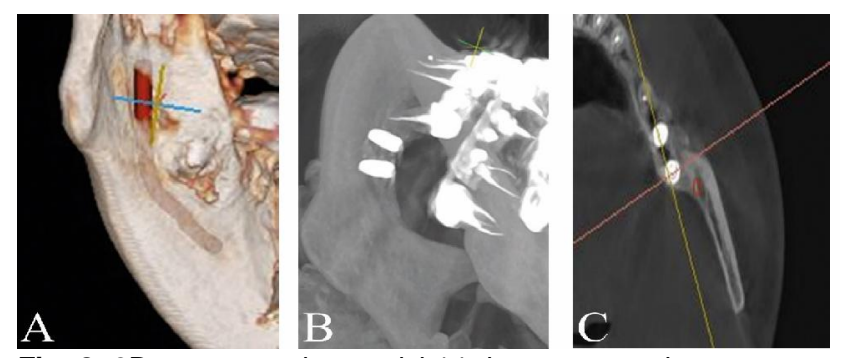

Fig. 8. 3D reconstruction model 14-day postoperative treatment period.

various mechanisms of wound healing. For example: av$\beta 3$-interleukin, the expression of which is induced by fibrin with the help of endothelial cells, together with fibronectin stimulate the process of formation of capillaries, as well as remodeling processes, the patterns of which we used in this clinical case (Fig. 7).

No less exciting clinical stage is postoperative radiological control in the early and long periods of dispensary supervision. The X-ray shadow with differentiation of shades of gray that is positive and expected result of the given treatment is accurately visualized on $3 \mathrm{D}$ reconstruction models of the presented image. Also, the protocol of preparation and installation of implants on observance of the basic principles of biological expediency and physiological ability and technical rationality that is shown in Fig. 8 is observed.

\section{Discussion}

After the analysis of the primary medical documentation of the patient $\mathrm{J}$. (form 043 / $\mathrm{o}$ and radiological images), the absence of the follicular bud of 38 tooth was revealed. After all, during follicular growth and in the direction of its vertical movement, there is an appositional growth of the cellular part of the lower jaw. This factor negatively affected the development of bone tissue of the jaw segment and thus contributed to the development of "disuse atrophy" and corticalization of the trabecular layer of the bone. Its morphological adjustment, due to the early loss of 36,37 teeth also attracts attention. Constant movements and the corresponding pressure from the tongue, as well as functional movements and strength of the masticatory muscles led to deformation of the body with the acquisition of a "sigmoid" shape of the jaw (Fig. 9)

The known significance of the mechanical effect on bone mass, described in Wolf's transformation law (1892), any change in function leads to anatomical and structural changes in the tissues and organs involved in this function.

From a clinical point of view, physiological osseointegration as well as desosteointegration depend directly on the presence of teeth, which transfer functional load to bone tissue and thus stimulate constant remodeling processes, during which it is resorbed by osteoclasts, at the same time replaced by new biological material, depending on the state of the human macroorganism or "controlled" impact [27-29, 35-37], with its qualitative and quantitative characteristics. Otherwise, the lack of load does not create conditions for bone remodeling processes, ie does not promote its regeneration, which distorts the biological basis and leads to corticalization or "devastation" of the trabecular layer.

Therefore, such bone tissue, as shown by clinical practice, needs to be restored by using biocompatible materials [31, 35, 42], which will stimulate bone regeneration without scar tissue formation, ie increased ossification and control of the effectiveness of coenzyme vitamin D3 [21].

The architecture of bone tissue in the ratio of the cortical to the trabecular layer directly depends on its blood supply. High bone density, respectively, has a high risk, in this case, to the development of atrophy in the vertical direction, both of the cell and the body segment of the lower jaw.

We know the studies of the authors who compared and

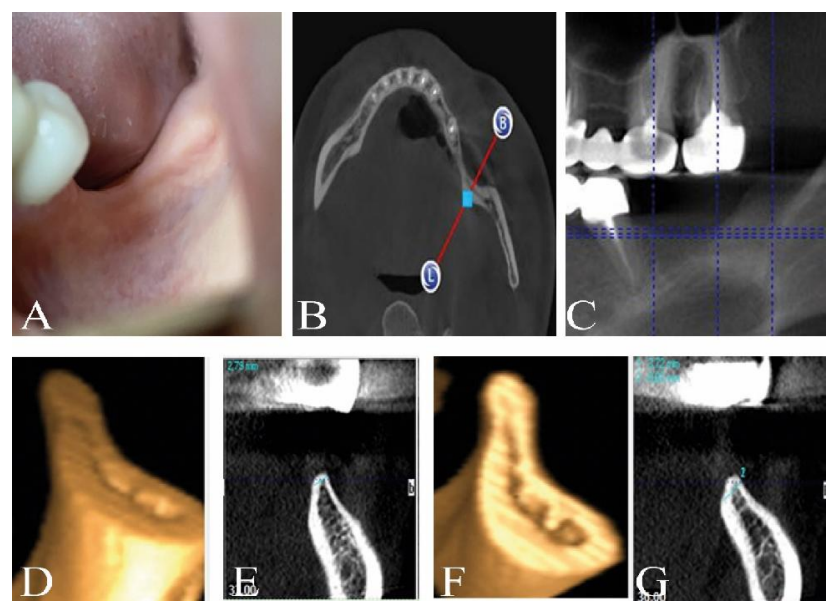

Fig. 9. The final defect of the dentition of the lower jaw on the left. "Disuse" atrophy due to early tooth loss (28 years). Sagittal section of a $3 \mathrm{D}$ reconstruction model of the left lower jaw. 


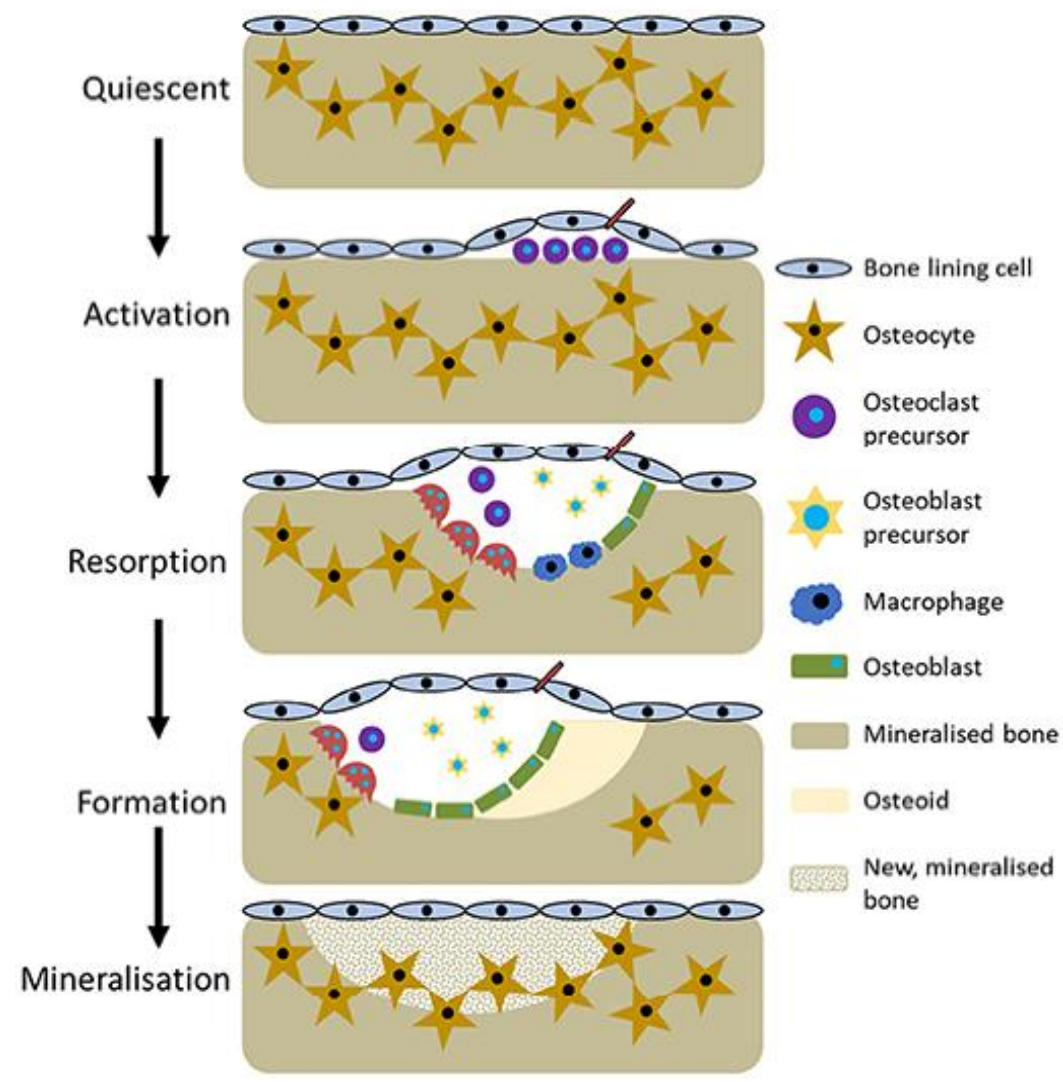

Fig. 10. Scheme of metabolic processes of bone tissue (Owen, R., Reilly, G. C., 2018).

compiled a table of correspondence of bone tissue biotypes D1, D2, D3, D4 on the Hounsfield scale (HU): biotype D1 density> $1250 \mathrm{HU}$, it occurs in the lower jaw, in half the cases in the chin; it is practically not found on the upper jaw; biotype D2 - density from 850 to $1250 \mathrm{HU}$, the most common type of bone tissue; biotype D3 - density from 350 to $850 \mathrm{HU}$, which is characteristic of the lateral parts of the lower and upper jaws in $50 \%$, especially in the area of the premolars, and approximately for $25 \%$ of the anterior zone of the edentulous lower jaws; biotype D4 - density $<350 \mathrm{HU}$, in the vast majority of cases occurs on the upper jaw.

Metabolic processes in trabeculae significantly exceed metabolic activity in a number of diseases [3, 19, 23, 39, 45]. Also, the reduction of the functional load on the bone significantly affects the magnitude of biopotentials and the activity of osteoblasts, as a result of which the process of resorption again prevails over the process of osteogenesis.

Analyzing the presented scheme of "metabolic" transformations of bone tissue (Fig. 10), which is

\section{Reference:}

[1] Abdullah, W. A. (2016). Evaluation of bone regenerative capacity in rats claverial bone defect using platelet rich fibrin with and without beta tri calcium phosphate bone graft material. Saudi Dent J, 28(3), 109-117. doi: 10.1016/j.sdentj.2015.09.003

[2] Anitua, E., Prado, R., Troya, M., Zalduendo, M., de la Fuente, M., Pino, A., ... \& Orive, G. (2016). Implementation of more characterized by their patterns, it was found that the lack of indirect effects is asynchronously reflected in the qualitative characteristics in the ratio of organic component to mineral saturation, thereby determining its quantitative morphology as in this clinical case, led to the development of "disuse atrophy".

To date, the choice of clinician has a significant number of methods [5, 11-13, 15, 25] and materials [34], which contribute to some extent to achieve the goals or objectives. However, due to the volume of their clinical protocols, as well as technical support and economic justification, it deprives the doctor of proper use, or their fragmentary use does not give the expected result [44]. It is, taking as a matrix basis autologous "products" obtained using ENDORET PRGF technology, we have a positive result that meets the basic principles of the goal to ensure the mechanisms of physiological processes of normal quantitative and qualitative morphology of bone tissue, with its biological characteristics which highlights the novelty of the study in this work.

No less important factor is the simplicity of the method, because one macroorganism is the donor and recipient, ie the patient himself, who is always "available" and eliminates significant clinical risks, contraindications to transplantation and its rational ergonomics and thus gains priority among existing methods in practical application [46 48-50]. Therefore, based on the prospects of further research in this area, we see a detailed study of changes in bone density of the human lower jaw with the loss of teeth of people of different ages of postnatal ontogeny.

This manuscript is based on the observance of moral and ethical norms and has no signs of conflict of interest between the authors and the patient.

\section{Conclusion}

This clinical experience with the use of autocellular grafts in the treatment of "disuse atrophy" of the bone tissue of the jaws, which is essentially scientifically-research in nature, based on modern, at the same time available technologies of cell engineering and technical progress, deserves further research and practical testing

physiological plasma rich in growth factor (PRGF) protocol: Anticoagulant removal and reduction in activator concentration. J. Platelets, 27(5), 459-466. doi: 10.3109/ 09537104.2016.1143921

[3] Annibali, S., Pranno, N., Cristalli, M. P., La Monaca, G., \& Polimeni, A. (2016). Survival Analysis of Implant in Patients With Diabetes 
Mellitus: A Systematic Review. Implant Dent, 25(5), 663-674. doi: 10.1097/ID.0000000000000478

[4] Avetikov, D. S., Pronina, O. M., Lokes, K. P., \& Bukhanchenko, O.P. (2017). Сучасні уявлення про умови, які обмежують вибір методу дентальної імплантації на верхніх і нижніх щелепах [Modern ideas about the conditions that limit the choice of method of dental implantation in the upper and lower jaws]. Вісник проблем біології і медицини - Bulletin of problems of biology and medicine. 4(3), 20-27. doi: 10.29254/ 2077-4214-2017-4-3-141-20-27

[5] Bahrii, M. M., Dibrova, V. A., Popadynets, O. H., \& Hryshchuk, M. I. (2016). Методики морфологічних досліджень:монографрія; за ред. М. М. Багрія, В. А. Діброви [Methods of morphological research: monograph; edited by M. M. Bahrii, V. A. Dibrova]. Vinnytsia: New Book, 2016.

[6] Barbeck, M., Najman, S., Stojanovic, S., Mitic, Z., Zivkovic, J. M, Choukroun, J., ... \& Ghanaati, S. (2015). Addition of blood to a phycogenic bone substitute leads to increased in vivo vascularization. Biomed Mater (Bristol, England), 10(5), 055007. doi: 10.1088/1748-6041/10/5/055007

[7] Barylo, O. S., Kanishyna, T. M., \& Biloshytska, A. V. (2017). Дослідження впливу фібріну, збагаченого тромбоцитами (platelet rich fibrin, prf), на регенерацію тканин парадонта в експерименті [Study of the effect of platelet-enriched fibrin (platelet rich fibrin, prf) on the regeneration of periodontal tissues in the experiment]. Український стоматологічний альманах - Ukrainian Dental Almanac, (2), 5-8.

[8] Bassetti, M. A., Bassetti, R. G., \& Bosshardt, D. D. (2016). The alveolar ridge splitting/expansion technique: a systematic review. Clin Oral Implants Res, 27(3), 310-324. doi: 10.1111/ clr. 12537

[9] Bassetti, M., Kaufmann, R., Salvi, G. E., Sculean, A., \& Bassetti, R. (2015). Soft tissue grafting to improve the attached mucosa at dental implants: A review of the literature and proposal of a decision tree. Quintessence Int, 46(6), 499-510. doi: 10.3290/ j.qi.a33688

[10] Cai, X., Xing, J., Long, C., Peng, Q., \& Beth Humphrey, M. (2017). DOK3 modulates bone remodeling by negatively regulating osteoclastogenesis and positively regulating osteoblastogenesis. J. Bone Miner. Res, (32), 2207-2218. doi: 10.1002/jbmr.3205

[11] Carlino, F., Pantaleo, G., Ciuffolo, F., Claudio, P. P., \& Cortese, A. (2016). New Technique for Mandibular Symphyseal Distraction by a Double-Level Anchorage and Fixation System: Advantages and Results. J Craniofac Surg, 27(6), 1469-1475. doi: $10.1097 /$ scs.0000000000002831

[12] Chang, A. T., Liu, Y., Ayyanathan, K., Benner, Ch., Jiang, Y., Prokop, J. W., ... \& Yang, J. (2015). An evolutionarily conserved DNA architecture determines target specificity of the TWIST family bHLH transcription factors. Genes dev, 29(6), 603616. doi: $10.1101 /$ gad.242842.114

[13] Cortese, A., Pantaleo, G., Amato, M., \& Claudio, P. P. (2016). Ridge Expansion by Flapless Split Crest and Immediate Implant Placement: Evolution of the Technique. J Craniofac Surg, 27(2), e123-128. doi: 10.1097/SCS.0000000000002367

[14] Cortese, A., Pantaleo, G., Borri, A., Caggiano, M., \& Amato, M. (2016). Platelet-rich fibrin (PRF) in implant dentistry in combination with new bone regenerative technique in elderly patients. Int J Surg Case Rep, (28), 52-56. doi: 10.1016/ j.ijscr.2016.09.022

[15] Du, Z., Xiao, Y., Hashimi, S., Hamlet, S. M., \& Ivanovski, S. (2016). The effects of implant topography on osseointegration under estrogen deficiency induced osteoporotic conditions:
Histomorphometric, transcriptional and ultrastructural analysis. Acta Biomater, (42), 351-363. doi: 10.1016/ j.actbio.2016.06.035

[16] Figliuzzi, M. M., Giudice, A., Pileggi, S., Pacifico, D., Marrelli, M., Tatullo, M., \& Fortunato, L. (2016). Implant-Prosthetic Rehabilitation in Bilateral Agenesis of Maxillary Lateral Incisors with a Mini Split Crest. Case Rep Dent, 2016, 3591321. doi: 10.1155/2016/3591321

[17] Fujioka-Kobayashi, M., Schaller, B., Saulacic, N., Zhang, Y., \& Miron. R. J. (2017). Growth factor delivery of BMP9 utilizing a novel natural bovine bone graft with integrated atelo-collagen type I: Biosynthesis, characterization and cell behavior. $J$ Biomed Mater Res A, 105(2), 408-418. doi: 10.1002/ jbm.a.35921

[18] Fujioka-Kobayashi, M., Miron, R. J., Hernandez, M., Kandalam, U., Zhang, Y., \& Choukroun, J. (2017). Optimized platelet rich fibrin with the low speed concept: growth factor release, biocompatibility and cellular response. J. Periodontol, 88(1), 112-121. doi: 10.1902/jop.2016.160443

[19] Giro, G., Chambrone, L., Goldstein, A., Rodrigues, J. A., Zenobio, E., Feres, M., ... \& Shibli, J. A. (2015). Impact of osteoporosis in dental implants: A systematic review. World journal of orthopedics, 6(2), 311-315. doi: 10.5312/wjo.v6.i2.311

[20] Grigorov, S. M., Krynychko, L. R., Steblovsky, D. V., Stavytsky, S. O., \& Akhmerov, V. D. (2018). Сучасний погляд на експериментальне і клінічне обгрунтування використання prf у процесах репаративної регенерації шкіри [Modern view on the experimental and clinical justification of the use of prf in the processes of reparative skin regeneration]. Український стоматологічний альманах - Ukrainian Dental Almanac, (2), 45-48.

[21] Javed, F., Malmstrom, H., Kellesarian, S. V., Al-Kheraif, A. A., Vohra, F., \& Romanos, G. E. (2016). Efficacy of Vitamin D3 Supplementation on Osseointegration of Implants. Implant dentistry, 25(2), 281-287. doi: 10.1097/ID.0000000000000390

[22] Ketabi, M., Deporter, D., \& Atenafu, E. G. (2016). A Systematic Review of Outcomes Following Immediate Molar Implant Placement Based on Recently Published Studies. Clin Implant Dent Relat Res, 18(6), 1084-1094. doi: 10.1111/cid.12390

[23] King, S., Klineberg, I., Levinger, I., \& Brennan-Speranza, T. C. (2016). The effect of hyperglycaemia on osseointegration: a review of animal models of diabetes mellitus and titanium implant placement. Arch Oosteoporos, 11(1), 29. doi: 10.1007/ s11657-016-0284-1

[24] Kohli, N., Ho, S., Brown, S. J., Sawadkar, P., Sharma, V., Snow, M., \& Garcia-Gareta, E. (2018). Bone remodelling in vitro: where are we headed? - A review on the current understanding of physiological bone remodelling and inflammation and the strategies for testing biomaterials in vitro. Bone, (110), 38-46. doi: 10.1016/j.bone.2018.01.015

[25] Langdahl, B., Ferrari, S., \& Dempster, D. W. (2016). Bone modeling and remodeling: potential as therapeutic targets for the treatment of osteoporosis. Ther. Adv. Musculoskel. Dis, (8), 225-235. doi: 10.1177/1759720X16670154

[26] Liu, M., Sun, Y., \& Zhang, Q. (2018). Emerging role of extracellular vesicles in bone remodeling. J. Dental Res, (97), 859-868. doi: 10.1177/0022034518764411

[27] Liu, S., Zhu, W., Li, S., Ma, J., Zhang, H., Li, Z., ... \& Shi, W. (2016). Bovine parathyroid hormone enhances osteoclast bone resorption by modulating V-ATPase through PTH1R. Int. J. Mole. Med., (37), 284-292. doi: 10.3892/ijmm.2015.2423

[28] Luo, G., Sun, S. J., Weng, T. J., Li, X. M., Wang, Z. G., \& Zhang, B. (2016). Effect of osteoclasts on murine osteoblastic 
differentiation in early stage of co-culture. Int. J. Clin. Exp. Med., (9), 1062-1072.

[29] Mandatori, D., Penolazzi, L., Pipino, C., Di Tomo, P., Di Silvestre, S., Di Pietro, N., ... \& Assunta, P. (2017). Menaquinone-4 enhances osteogenic potential of human amniotic fluid mesenchymal stem cells cultured in a 2D and 3D dynamic culture system. J. Tissue Eng. Regenerat. Med., (12), 447459. doi: 10.1002/term. 2471

[30] Meloni, S. M., Jovanovic, S. A., Urban, I., Canullo, L., Pisano, M., \& Tallarico, M. (2017). Horizontal ridge augmentation using GBR with a native collagen membrane and $1: 1$ ratio of particulated xenograft and autologus bone: a 1-year prospective clinical study. Clin Implant Dent Relat Res, 19(1), 38-45. doi: 10.1111 / cid. 12429

[31] Mestas, G., Alarcon, M., \& Chambrone, L. (2016). Long-Term Survival Rates of Titanium Implants Placed in Expanded Alveolar Ridges Using Split Crest Procedures: A Systematic Review. Int J Oral Maxillofac Implants, 31(3), 591-599. doi: 10.11607/ jomi.4453

[32] Miron, R. J., Fujioka-Kobayashi, M., Hernandez, M., Kandalam, U., Zhang, Y., Ghanaati, S., \& Choukroun, J. (2017). Injectable platelet rich fibrin (i-PRF): opportunities in regenerative dentistry? Clin Oral Investig, 21(8), 2619-2627. doi: 10.1007/ s00784-017-2063-9

[33] Miron, R. J., Fujioka-Kobayashi, M., Bishara, M., Zhang, Y., Hernandez, M., \& Choukroun, J. (2017). Platelet-Rich Fibrin and Soft Tissue Wound Healing: A Systematic Review. Tissue Eng Part B Rev, 23(1), 83-99. doi: 10.1089/ten. TEB.2016.0233

[34] Nelson, K., Schmelzeisen, R., Taylor, T. D., Zabler, S., Wiest, W., \& Fretwurst, T. (2016). The Impact of Force Transmission on Narrow-Body Dental Implants Made of Commercially Pure Titanium and Titanium Zirconia Alloy with a Conical ImplantAbutment Connection: An Experimental Pilot Study. The International journal of oral \& maxillofacial implants, 31(5), 1066-1071.

[35] Owen, R., \& Reilly, G. C. (2018). In vitro Models of Bone Remodelling and Associated Disorders. Frontiers in bioengineering and biotechnology, (6), 134. doi: 10.3389/ fbioe.2018.00134

[36] Paiva, K. B. S., \& Granjeiro, J. M. (2017). Matrix metalloproteinases in bone resorption, remodeling, and repair. Progress Mole. Biol. Transl. Sci., (148), 203-303. doi: 10.1016/ bs.pmbts.2017.05.001

[37] Penolazzi, L., Lolli, A., Sardelli, L., Angelozzi, M., Lambertini, E., Trombelli, L., ... \& Piva, R. (2016). Establishment of a 3Ddynamic osteoblasts-osteoclasts co-culture model to simulate the jawbone microenvironment in vitro. Life Sci, (152), 82-93. doi: 10.1016/j.lfs.2016.03.035

[38] Puisys, A., \& Linkevicius, T. (2015). The influence of mucosal tissue thickening on crestal bone stability around bone-level implants. A prospective controlled clinical trial. Clinical oral implants research, 26(2), 123-129. doi: 10.1111 / clr.12301

[39] Ricci, D., \& Aymetti, M. (2015). Диагностика и лечение заболеваний пародонта [Diagnosis and treatment of periodontal diseases]. Москва: Издательский дом "Азбука стоматолога" - Moscow: "Alphabet of the dentist" Publishing House.

[40] Rubert, M., Vetsch, J. R., Lehtoviita, L., Hofmann, S., \& Muller, R. (2017). Bone remodelling imaging in a human-based in vitro co-culture model-A proof of concept. In eCM Meeting Abstract Collect. (Vol. 2, p. 29). doi: 10.20944/preprints 201702.0047.v1

[41] Rybak, V. A., Natrus, L. V., Kopchak, A. V., Pavlychuk, T. O., \&
Chernovol, P. А. (2017). Чинники, що впливають на вміст та функціональні властивості тромбоцитів у плазмі, збагаченій факторами росту (PRGF Endoret) [Factors influencing the content and functional properties of platelets in plasma enriched with growth factors (PRGF Endoret)]. Медицина неотложных состояний - Emergency medicine, 1(80), 159-167.

[42] Siebert, T., Jurkovic, R., Statelova, D., \& Strecha, J. (2015). Immediate Implant Placement in a Patient With Osteoporosis Undergoing Bisphosphonate Therapy: 1-Year Preliminary Prospective Study. The Journal of oral implantology, (41), 360-365. doi: 10.1563/AAID-JOI-D-13-00063

[43] Solodzhuk, Yu. I., Rozhko, M. M., Denysenko, O. H., \& Yarmoshuk, I. R. (2019). Використання остеопластичного матеріалу тваринного походження при атрофії коміркового відростка верхньої щелепи та частини нижньої щелепи в поєднанні з осеїн-гідроксиапатитним комплексом [The use of osteoplastic material of animal origin in atrophy of the cellular process of the upper jaw and part of the lower jaw in combination with ossein-hydroxyapatite compound]. Вісник проблем біології і медицини - Bulletin of problems of biology and medicine, 1(2), 254-258. doi: 10.29254/20774214-2019-1-2-149-254-258

[44] Sprangers, S., \& Everts, V. (2017). Molecular pathways of cell-mediated degradation of fibrillar collagen. Matrix Biology, (75), 190-200. doi: 10.1016/j.matbio.2017.11.008

[45] Suzuki, A., Sangani, D. R., \& Ansari, A. (2015). Molecular mechanisms of midfacial developmental defects. Dev Dyn, (245), 276-293. doi: 10.1002/dvdy.24368

[46] Troiano, G., Laino, L., Dioguardi, M., Giannatempo, G., Muzio, L., \& Russo, L. (2016). Mandibular Class II Furcation Defect Treatment: Effects of the Addition of Platelet Concentrates to Open Flap: A Systematic Review and Meta-Analysis of Randomized Clinical Trials. J Periodontol, 87(9), 1030-1038. doi: 10.1902/jop.2016.160058

[47] Usenko, O. Yu., Radyoha, Ya. V., Grebeniuk, D. I., \& Stukan, O. К. (2015). Поєднання клітинних технологій та мініінвазивної хірургії в лікуванні хронічної виразки шлунка [Combination of cells technologies and minsiinvasive surgery in the treatment of chronic gastric ulcer]. Клінічна хірургія Klin Khir, (10), 25-28. PMID: 26946654

[48] Wang, Q. S., Wang, G. F., Lu, Y. R., Cui, Y. L., Li, H., Li, R. X., ... \& Liu T. J. (2017). The Combination of icariin and constrained dynamic loading stimulation attenuates bone loss in ovariectomy-induced osteoporotic mice. J. Orthop. Res., (36), 1415-1424. doi: 10.1002/jor.23777

[49] Yuan, F.-L., Wu, Q.-y., Miao, Z.-N., Xu, M.-H., Xu, R.-S., Jiang, D.-L., ... \& Li, X. (2018). Osteoclast-derived extracellular vesicles: novel regulators of osteoclastogenesis and osteoclast-osteoblasts communication in bone remodeling. Front. Physiol., (9), 628. doi: 10.3389/fphys.2018.00628

[50] Zhang, J., Shirai, M., Yamamoto, R., Yamakoshi, Y., Oida, S., Ohkubo, C., \& Zeng, J. (2016). Effect of Nerve Growth Factor on Osseointegration of Titanium Implants in Type 2 Diabetic Rats. J Oral Maxillofac Implants, 31(5), 1189-1194. doi: 10.11607/jomi.4455

[51] Zhang, Y., Yang, S., Zhou, W., Fu, H., Qian, L., \& Miron, R. J. (2016). Addition of a Synthetically Fabricated Osteoinductive Biphasic Calcium Phosphate Bone Graft to BMP2 Improves New Bone Formation. Clin Implant Dent Relat Res, 18(6), 1238-1247. doi: 10.1111/cid.12384 